\title{
Selenium and other potentially toxic elements in vegetables and tissues of three non-migratory birds exposed to soil, water, and aquatic sediment contaminated with seleniferous Raša coal
}

The Mining-Geology-Petroleum Engineering Bulletin UDC: $504: 553.4$ DOI: $10.17794 /$ rgn.2018.3.6

Original scientific paper \author{
Adela Krivohlavek $^{2}$, Goran Kniewald ${ }^{3}$, Lucija Dujmović ${ }^{6}$ \\ ${ }^{1}$ University of Zagreb, Faculty of Science, Department of Geology, Zagreb, Croatia \\ ${ }^{2}$ Andrija Štampar Teaching Institute of Public Health, Zagreb, Croatia \\ ${ }^{3}$ Ruđer Bošković Institute, Division for Marine and Environmental Research, Zagreb, Croatia \\ ${ }^{4}$ Society 'Istrian coal mines Raša', Nikole Tesle 1, Raša, 52223, Croatia \\ ${ }^{5}$ Banaras Hindu University, Department of Botany, Varanasi, Uttar Pradesh, India \\ ${ }^{6}$ University of Zagreb, Faculty of Science, Department of Biology, Zagreb, Croatia
}

Gordana Medunić', Željka Kuharićz, Željka Fiket³, Mladen Bajramović4, Asha Lata Singh ${ }^{5}$,

\begin{abstract}
Coal mining and coal combustion release environmental contaminants which stay at emission sites for many decades. This paper reports total Se and other potentially toxic elements ( $\mathrm{As}, \mathrm{Cd}, \mathrm{Cu}, \mathrm{Cr}, \mathrm{Hg}, \mathrm{Pb}, \mathrm{Sr}, \mathrm{U}, \mathrm{V}$, and $\mathrm{Zn}$ ) in lettuce, potato, and tissues (liver, kidney, heart, and muscle) of three non-migratory bird species (pigeon, jay, and black coot) from the Raša Bay area (North Adriatic, Croatia). They have presumably been exposed to elevated levels of the mentioned elements in garden soil, surface water, and aquatic sediment contaminated with superhigh-organic-sulphur (SHOS) Raša coal, highly enriched in S, Se, V, and U. Results point at selenium contamination of stream water (up to $78 \mu \mathrm{g} / \mathrm{L}$ total Se in a non-filtered sample), which is well above the Croatian regulatory threshold of $10 \mu \mathrm{g} / \mathrm{L}$ total Se. The stream drains a site of the former coal-separation unit, and an associated bottom sediment contains up to $10.8 \mathrm{mg} / \mathrm{kg}$ total Se, which is also above the safe level of $0.60 \mathrm{mg} / \mathrm{kg}$ total Se. Moreover, values of Mo, U, V, and Sr, elements commonly elevated in SHOS coal varieties, were also increased in the majority of water samples as well as in analysed vegetables, soil, and aquatic sediments. Although $\mathrm{Cu}, \mathrm{Zn}, \mathrm{Pb}$, and $\mathrm{V}$ were slightly increased in liver samples of birds, more in black coot than the other two birds, selenium values were found to be adequate for their normal growth. The fact that Se can be environmentally hazardous and toxic to life, even in small doses, warrants further research on this topic.
\end{abstract}

Keywords:

coal, selenium, water, lettuce, birds.

\section{Introduction}

Coal is an indispensable source of energy in today's society which is highly dependent on electricity. It is well-known that its combustion releases environmental contaminants like sulphur (Singh et al., 2013; Saikia et al., 2015), and aerosol particles enriched in potentially toxic trace elements (Clarke \& Sloss, 1992; Silva et al., 2012; Singh et al., 2012; Oliveira et al., 2014; Kumar et al., 2015; Banerjee et al., 2016). However, coal and its by-products (ash) are the sources of economically valuable metals (Dai \& Finkelman, 2017), and medically active substances (Wang et al., 2014). Recently, coal is being used for the production of nanomaterials (Das et al., 2017), and tested for bioremediation (Singh et al., 2012) and clean-coal (Saikia et al., 2016) technological purposes. Back in the past, lacking legislative measures and non-existent clean-coal technologies had

Corresponding author: Gordana Medunić

gmedunic@geol.pmf.hr resulted in adverse effects of coal mining, coal combustion, and improper waste disposal on the environment (Helios Rybicka, 1996; Baruah \& Khare, 2010; Sofilić et al., 2013). The Raša Bay area (see Fig. 1) provides an example of such an environmental issue. The Raša town has been a major source of the Croatian energy production for more than 100 years. SHOS Raša coal seams were mined at nearby localities, from the second half of the 18th century until the late 1990s (Medunić et al., 2016a). A medical study (Mohorović, 2003) established the correlation between ground $\mathrm{SO}_{2}$ levels and health problems of pregnant women and small children due to exceptionally high $\mathrm{S}$ values in superhigh-organic-sulphur (SHOS) Raša coal (Medunić et al., 2017). Medunić et al. (2016b) determined that soil around a coalfired power plant (PPP), which used SHOS coal during the period between 1970 and 2000, is severely polluted with $\mathrm{S}$, polycyclic aromatic hydrocarbons (PAHs), Se, and $\mathrm{Cd}$, while Fiket et al. (2016) determined peculiar REE patterns in the studied soil samples. Since Se val- 


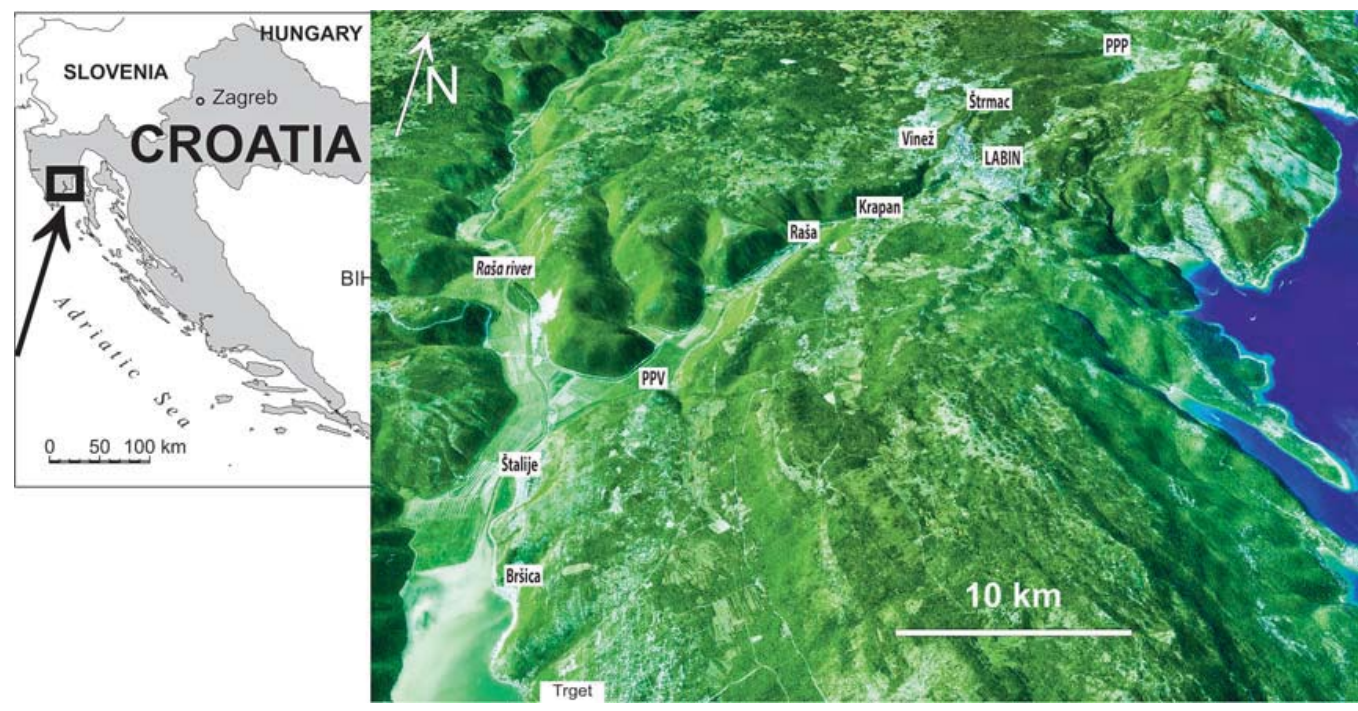

Figure 1: Map of the study area - soil and vegetable samples were collected from two private gardens in Raša town; positions of water and aquatic sediment sampling sites are explained in the main text

ues are markedly increased in SHOS Raša coal compared to coal Clarke values (Yudovich \& Ketris, 2006), Medunić et al. (2017) found slightly increased Se in aquatic (seawater of the Plomin Bay) and herbal (clover and foliage) samples. A similar enrichment of Se as well as U, Mo, Re, and V in SHOS Guiding coals (China) was discussed by Dai et al. (2015). Also, Medunić et al. (2017) reported decreased Se values in an old SHOS ash, subjected to natural weather conditions, compared to previously conducted studies on fresh SHOS ash. These findings point at a possible rain-driven leaching of Se throughout the environment of the study area, similarly to the leaking of US coal ash ponds (B, Sr, SO4, $\mathrm{Ca}, \mathrm{Mn}, \mathrm{Fe}, \mathrm{Se}, \mathrm{As}, \mathrm{Mo}$, and V) to adjacent surface water and shallow groundwater (Harkness et al., 2016).

According to Clarke \& Sloss (1992), energy production has been the largest single global source of $\mathrm{Hg}, \mathrm{Ni}$, and $\mathrm{V}$, and an important, but lesser source of $\mathrm{Cd}, \mathrm{Sb}$, and Se. Also, they note that coal has been an important source of $\mathrm{Cd}$ and Se. Selenium is an element the low levels of which play an essential role in living beings, while the difference between them and the toxic Se levels is rather narrow (Rayman, 2012), compared with the ranges for most other essential trace elements. Herewith, Lemly (2004) emphasized that a range of only a few $\mu \mathrm{g} / \mathrm{L}$ of waterborne Se can induce a transition from no effect to severe deformities and complete reproductive failure in fish. Lemly (1997) reviewed the environmental implications of excessive $\mathrm{Se}$ and the associated threats to fish and wildlife. The author discussed how rain-driven leachate and overflow rich in Se from coal piles and ash ponds could make its way into rivers and streams. Afterwards, Se gets bioaccumulated in aquatic food chains, contaminating the diet of fish, wildlife, and sometimes humans. Birds are considered bioindicators of potentially toxic trace element contamination of the environment. They can accumulate high levels of metals in their organs depending on food items, intensity and timing of exposure in foraging areas, and on a variety of physiological features (Kim et al., 1998). Ohlendorf \& Heinz (2011) point out that an assessment of the toxicity of Se is complicated by its occurrence in many different chemical forms, some differing greatly in their toxicity to birds. They also emphasize that an ability of Se to interact with other nutrients and environmental contaminants, especially other elements, sometimes complicates an interpretation of toxic thresholds in the tissues of birds. Herewith, the knowledge of a selenium content in the environment, food and animals from the Raša Bay area is highly necessary. Namely, the bay had been adversely impacted by coal mining, dirty coal preparation/ washing activities, coal storage sites and shipping (the Štalije and PPV sites in particular, see Fig. 1) for many decades during the 19th and 20th centuries. Therefore, the aim of this paper is to present for the first time the levels of $\mathrm{Se}, \mathrm{As}, \mathrm{Cd}, \mathrm{Cu}, \mathrm{Cr}, \mathrm{Hg}, \mathrm{Pb}, \mathrm{Sr}, \mathrm{U}, \mathrm{V}$, and $\mathrm{Zn}$ in tissues (liver, kidney, heart, and muscle) of three bird species (pigeon, jay, and black coot), presumably exposed to the water, soil, and aquatic sediment contaminated by SHOS Raša coal. Additionally, two Raša garden soils together with on-site lettuce and potato were collected to get an insight into selenium absorption from soil to plants.

\section{Methods}

\subsection{Site description and sampling strategy}

The study area (see Fig. 1) extends from the Raša town $\left(45^{\circ} 05^{\prime} \mathrm{N} 14^{\circ} 05^{\prime} \mathrm{E}\right)$ to the Raša River estuary (harbours Bršica, $45^{\circ} 02^{\prime} \mathrm{N} 14^{\circ} 03^{\prime} \mathrm{E}$, and Trget, $45^{\circ} 01^{\prime} \mathrm{N}$ 
$\left.14^{\circ} 03^{\prime} \mathrm{E}\right)$. Geological, hydrological, and pedological descriptions can be found elsewhere (Halamić et al. 2012; Miko et al. 1999). Briefly, the carbonate bedrock is composed of Mesozoic limestones and dolomites, overlain by thin to moderately thick red or brown clay-loam soils (Durn et al. 1999; Halamić et al. 2012). The soil is composed of quartz, plagioclase, K-feldspar, micas, kaolinite, chlorite, vermiculite, mixed-layer clay minerals, hematite, goethite, boehmite, and XRD-amorphous inorganic compounds (Miko et al. 1999). Former Raša coal mining towns (Štrmac, Labin, Vinež, Krapan, and Raša) had produced the most valuable deposits of lignite coal reserves in Croatia. Following their closure in 1999, shafts were flooded up to the water table and the water is flowing through the underground streams and surface channels right into the Raša River estuary. The Stalije location (see Fig. 1) served for the separation and washing of SHOS coal, while the dirty wastewater had been disposed of into the sea. The harbour Bršica served as a loading port for SHOS Raša coal in the past, and is specialised for the export of livestock and dangerous goods today.

Topsoil (down to a depth of $10 \mathrm{~cm}$ ) samples $(\mathrm{n}=2)$ were collected from two private gardens (Raša town), together with on-site lettuce $(n=1)$ and potato $(n=1)$, and their respective roots. In the laboratory, the roots were separated from edible parts, then washed with tap and distilled water, and rinsed with deionized water; the potato was peeled and cut into thin chips. Following the drying in an oven at $60^{\circ} \mathrm{C}$ for a few days, they were crushed in an agate mortar. Soil samples were air-dried, sieved through $<2 \mathrm{~mm}$, and homogenised in an agate mortar. Approximately $2 \mathrm{~kg}$ of aquatic sediments $(\mathrm{n}=2)$ were sampled from streams/channels draining the Štalije (water site no. 4) and PPV (water site no. 5) localities. Water was collected from seven localities as follows: 1/ the Raša River estuary, 2/ Trget (main beach), 3/ Trget (two main moles; the site of an inflow of technological waters of the port Raša-Bršica, the Raša River with its tributaries, and a Trget faecal effluent), 4/ the site of SHOS coal separation unit Štalije (a tributary of the Raša River), 5/ PPV (a left tributary of the Raša River; the site is a location of mixing of waters from the Krapan stream, faecal effluents of the Labin city and the Raša county, as well as underground Raša mine water and technological water of the PPV), 6/ the Krapan stream (a site where Raša coal mine water springs to the surface and inflows into the Krapan stream), and 7/ tap drinking water (the Raša town). All samples were, immediately after sampling, filtered through a syringe filter (pore size $0.45 \mu \mathrm{m})$ and, upon return to the laboratory, acidified with nitric acid $\left(1 \%(\mathrm{v} / \mathrm{v})\right.$ suprapur $\left.\mathrm{HNO}_{3}\right)$. Aliquots of filtered and unfiltered samples were subsequently stored at $4^{\circ} \mathrm{C}$ until further analysis. Three local, non-migratory birds (pigeon, jay, and black coot) were shot during the hunting season (early November 2017). Their tissues (liver, kidney, heart, and muscle) were carefully cut out and frozen at $-20^{\circ} \mathrm{C}$ until a subsequent element analysis.

\subsection{Analytical methods}

Element concentrations in water were determined in both filtered (dissolved) and unfiltered (total) samples. Samples from locations 1, 2 and 3 were diluted 10 times, while all other samples were processed without further dilution. Prior to analysis, all the samples were acidified with $2 \%(\mathrm{v} / \mathrm{v}) \mathrm{HNO}_{3}$ s.p. and In $(1 \mu \mathrm{g} / \mathrm{L})$ was added as an internal standard. Multielement analysis of the prepared water samples was performed by High Resolution Inductively Coupled Plasma Mass Spectrometry (HRICP-MS) using an Element 2 instrument (Thermo, Bremen, Germany). A detailed method description is given elsewhere (Fiket et al., 2007). External calibration was used for the quantification. Standards for multielement analysis were prepared by the appropriate dilution of a multielement reference standard (Analytika, Prague, Czech Republic) containing Al, As, Ba, Be, Cd, $\mathrm{Co}, \mathrm{Cr}, \mathrm{Cs}, \mathrm{Cu}, \mathrm{Fe}, \mathrm{Li}, \mathrm{Mn}, \mathrm{Mo}, \mathrm{Ni}, \mathrm{Pb}, \mathrm{Rb}, \mathrm{Sr}, \mathrm{Ti}, \mathrm{Tl}$, and $\mathrm{V}$ in which a single element standard solution of $\mathrm{U}$ (Aldrich, Milwaukee, WI, USA) was added. All samples were analysed for total concentration of following elements: Al, As, Ba, Be, Cd, Co, Cr, Cs, Cu, Fe, $\mathrm{Li}, \mathrm{Mn}$, $\mathrm{Mo}, \mathrm{Ni}, \mathrm{Pb}, \mathrm{Rb}, \mathrm{Sr}, \mathrm{Ti}, \mathrm{Tl}, \mathrm{U}$, and $\mathrm{V}$. Quality control of the analytical procedure was performed by simultaneous analysis of the blank and the certified reference material for water (SLRS-4, NRC, Canada). Good agreement between the analysed and the certified concentrations within their analytical uncertainties for all elements was obtained $( \pm 10 \%)$.

Subsamples $(0.5 \mathrm{~g})$ of bird tissues (muscle, liver, kidney, and heart) were subjected to a total digestion in the microwave oven (Microwave ECO, Anton Paar, Austria) with $7 \mathrm{~mL}$ of $\mathrm{HNO}_{3}$ and $0.1 \mathrm{~mL}$ of $\mathrm{HF}$ (Fiket et al., 2017). After the digestion, each solution was transferred to a pre-cleaned plastic volumetric flask and diluted to $25 \mathrm{~mL}$. Quality control of the analytical procedure was performed by simultaneous analysis of the blank and the certified reference material for muscle (NCS ZC 78005, also known as GBW-08571, China National Analysis Center for Iron and Steel, Bejing, China). Good agreement between the analysed and the certified concentrations within their analytical uncertainties for all elements was obtained $( \pm 8 \%)$.

Regarding soil and sediment dried and homogenised powder samples, an amount of $0.1 \mathrm{~g}$ of a sample was digested by microwave digestion with $5 \mathrm{~mL} \mathrm{HNO}_{3}$ and 1 $\mathrm{mL} \mathrm{H}_{2} \mathrm{O}_{2}$ (Milestone Ethos 1600 Microwave, Italy). Following the digestion, the samples were quantitatively transferred to a $50 \mathrm{~mL}$ graduated flask and supplemented to the label. In addition to the samples, a control sample of soil (BCR 143R, European commission joint research center, Institute for Reference Materials and Measurements) was prepared. An amount of $0.5 \mathrm{~g}$ of a vegetable dried and homogenised powder sample was treated by microwave digestion using $5 \mathrm{~mL} \mathrm{HNO}_{3}$ and $1 \mathrm{~mL} \mathrm{H}_{2} \mathrm{O}_{2}$ (Microwave ECO, Anton Paar, Austria). Following the

The Mining-Geology-Petroleum Engineering Bulletin and the authors @ , 2018, pp. 53-62, DOI: 10.17794/rgn.2018.3.6 
digestion, samples were quantitatively transferred to a $25 \mathrm{~mL}$ graduated flask and supplemented to the label. In addition to the samples, a control sample was prepared as a quality assurance test (Tomato Leaves 1573a, NIST). Multi-elemental analysis (Cd, Pb, Cr, Sr, V, Se, U, As, Hg) was carried out by ICP-MS (7800 Agilent). An external calibration was used by diluting the multi elemental standard solution (Sigma Aldrich). A single standard of mercury was added to the solution (Ultra Scientific, USA). As an internal standard, a solution of In, Sc, Ge, and Bi was used (Agilent). Copper and zinc concentrations were determined by flame measurement on AAS (SOLAAR SP 8, Thermo, UK). Sodium and Zn concentrations were determined by standard dilution calibration (Merck, USA). The BCR 143 R measurement results were within $\pm 10 \%$, while Tomato Leaves were within $\pm 7 \%$.

\section{Results and Discussion}

\subsection{Element levels in water samples}

Total (NF, i.e. dissolved and particle associated elements) and dissolved (F) levels of analysed elements in water samples are presented in Table 1. The site no. 1 is estuary, 2 and 3 are seawater samples, 4 is brackish, while 5 and 6 are freshwater ones. It is clear that the measured elements in tap water (sample no. 7) did not exceed the levels prescribed by the drinking water guideline. Diaz et al. (1996) reported average total Se values $(0.24 \pm 0.07 \mu \mathrm{g} / \mathrm{L})$ in potable waters from an industrial zone in southeastern Spain, which are much lower than $1 \mu \mathrm{g} / \mathrm{L}$ total Se in Raša tap water. On the other hand, Mo, $\mathrm{U}, \mathrm{Se}, \mathrm{Pb}, \mathrm{Al}, \mathrm{Mn}$, and Fe in estuary and seawater samples are well above the world seawater values reported by Reimann \& de Caritat (1998). Levels of Mo, U, and Se can be ascribed to the leaching of SHOS Raša coal particles in oxidative, alkaline conditions (Dreher \& Finkelman, 1992). SHOS coals are commonly enriched in U, Se, Mo, Re and V, and Chinese SHOS coals were investigated and interpreted by Dai et al. (2015) in relation to that particular feature. SHOS Raša coal particles were either buried in bottom marine sediments together with the wastewater from coal washing decades ago, or they are still left scattered in soils and surface sediments and washed away with precipitation. Adriano (2001) reports that river and lake waters from areas not impacted by pollution generally have Mo levels $<1 \mu \mathrm{g} / \mathrm{L}$, while surface waters reaching $5 \mu \mathrm{g} / \mathrm{L}$ or higher may be considered as anomalous. Although Mo is highly elevated in stream water samples too (see Table 1), according to Adriano (2001), the presence of large quantities of Mo in plants does not produce detrimental effects on crop yields or any toxicity appearance on the foliage. Similarly, $\mathrm{U}$ and $\mathrm{Se}$ are increased at almost all six (no. 1-6) sites, either in filtered or non-filtered samples. Vanadium was found elevated in stream samples, while its levels in seawater were only slightly below world values. These findings are in accordance with Kendall's tau correlation coefficients $(>0.99, p<0.05)$ calculated for all the pairs of S, Se, V and U in SHOS Raša coal samples, reported by Medunić et al. (2017). Uranium is a non-essential, chemotoxic, radiotoxic, and carcinogenic element, while $\mathrm{V}$ is an essential nutrient for many animals, but it can be toxic depending on its speciation and oxidation state (Reimann \& de Caritat, 1998). The worst case of selenium toxicity occurred in China in 1961-1964, caused by coal extremely enriched in Se (average $>300 \mu \mathrm{g} / \mathrm{g}$ ), when the morbidity rate was nearly $50 \%$ in 248 inhabitants of 5 villages, due to Se intoxication (Yang et al., 1983). The authors reported an average Se value of 139 $\mu \mathrm{g} / \mathrm{L}$ for surface water from a village which experienced a heavy prevalence of selenosis. Roughly a half amount of that value was found at the site no. 4, thus greatly exceeding the Croatian regulatory limit value for Se in surface water of $10 \mu \mathrm{g} / \mathrm{L}$. Lemly (1993) emphasize that much lower Se levels, e.g. 2-5 $\mu \mathrm{g} / \mathrm{L}$, pose concern, while Adriano (2001) point out that certain toxicological and reproductive effects are related to $\mathrm{Se}>5 \mu \mathrm{g} / \mathrm{L}$ in water. Lemly (1997) suggest that waterborne Se concentrations of $2 \mu \mathrm{g} / \mathrm{L}$ (total recoverable basis in $0.45 \mu \mathrm{m}$ filtered samples) or greater should be considered hazardous to the health and long-term survival of fish and wildlife populations, owing to dietary toxicity, reproductive effects, and food-chain bioaccumulation. Since that level was surpassed by water samples no. 4-6 (see Table 1), the pertaining sites should be inspected, preferably subjected to phytoremediation (Sasmaz \& Obek, 2009; Zacchini et al., 2009) or bioremediation (Singh et al., 2012; Sharma et al., 2017), and monitored afterwards. Diaz et al. (1996) reported average total Se values in waste waters and irrigation waters in Spain as follows: $0.13 \pm 0.08 \mu \mathrm{g} / \mathrm{L}$, and $0.17 \pm 0.14 \mu \mathrm{g} / \mathrm{L}$, respectively. The authors also compared them with relevant values in Belgium (0.35 $\mu \mathrm{g} / \mathrm{L})$, England (1.1-3.3 $\mu \mathrm{g} / \mathrm{L})$, Israel $(0.44 \mu \mathrm{g} / \mathrm{L})$, Germany $(0.12 \mu \mathrm{g} / \mathrm{L})$, the Netherlands $(0.12 \mu \mathrm{g} / \mathrm{L})$, and New York $(<0.2 \mu \mathrm{g} / \mathrm{L})$. These values are well below the majority of the Raša stream Se levels shown in Table 1. Ternjej et al. (2013) measured heavy metals in Croatian karst water from an area geologically similar to the Raša study area, and their levels, mostly lower than the heavy metal values in Table 1 , are as follows $(\mu \mathrm{g} / \mathrm{L})$ : $\mathrm{Cd} 0.01, \mathrm{Cr}<0.01, \mathrm{Cu} 0.26, \mathrm{~Pb} 0.01, \mathrm{Sr}$ 601 , V 0.18, and Zn 0.60. Hereby, the aquatic Mo-Se-U$\mathrm{V}$ levels clearly evidence the leaking problem related to SHOS Raša coal which has been polluting the local environment still today, 4-5 decades after the coal production was terminated.

In regard to the other measured elements, $\mathrm{Pb}$ was found elevated in some seawater and stream samples, while $\mathrm{Al}, \mathrm{Mn}$, and Fe were increased only in seawater samples (see Table 1). They could be related partly to suspended particle load from the Raša River (Juračić et al., 1994), and partly to today's activities in and around 
Table 1: Concentrations of measured elements in water samples ( $\mathrm{F}$ - filtered through $0.45 \mu \mathrm{m}$, NF - non-filtered; site names explained in main text and Fig. 1). Reference values (WSW ${ }^{\mathrm{a}}$ - world seawater, WRW ${ }^{\mathrm{a}}$ - world river water, DWG ${ }^{\mathrm{b}}-$ drinking water guideline): Reimann \& de Caritat $(\mathbf{1 9 9 8})^{\mathrm{a}}$, and OG (2008) ${ }^{\mathrm{b}}$. Underlined values exceed relevant reference levels

\begin{tabular}{|c|c|c|c|c|c|c|c|c|c|c|c|c|c|c|c|c|c|c|}
\hline $\mathrm{g} / \mathrm{L}$ & & Mo & $\mathrm{Cd}$ & Cs & $\mathrm{Tl}$ & $\mathrm{Pb}$ & $\mathrm{U}$ & $\mathrm{Al}$ & $\mathrm{V}$ & $\mathrm{Cr}$ & $\mathrm{Mn}$ & $\mathrm{Fe}$ & $\mathrm{Ni}$ & $\mathrm{Cu}$ & $\mathrm{Zn}$ & $\mathrm{Sr}$ & As & $\mathrm{Se}$ \\
\hline $1 \mathrm{NF}$ & \multirow{2}{*}{$\begin{array}{l}\text { Raša } \\
\text { River } \\
\text { estuary }\end{array}$} & 29 & .08 & & 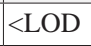 & D & 7 & .9 & 3 & $\mathrm{D}$ & 2.3 & $\underline{0}$ & 24 & $\mathrm{D}$ & 3 & 0 & 72 & 0.49 \\
\hline $1 \mathrm{~F}$ & & 8 & 06 & 2 & OD & 6 & 6 & 6.2 & 24 & $\mathrm{D}$ & $\underline{12.8}$ & 6.2 & 8 & $\mathrm{D}$ & 0 & 30 & 60 & 1.91 \\
\hline NF & \multirow{2}{*}{$\begin{array}{l}\text { Trget } \\
\text { beach }\end{array}$} & & 11 & & $\mathrm{OD}$ & $\underline{0.11}$ & 4.25 & 54.9 & 26 & $\mathrm{OD}$ & 3.93 & 53.2 & 5 & $\mathrm{OD}$ & $D$ & 80 & 63 & .07 \\
\hline$F$ & & 8.8 & .15 & 35 & $<$ LOD & $\underline{0.53}$ & 4.16 & 32.0 & 22 & LOD & 4.26 & 45.7 & .18 & $<$ LOD & 80 & 260 & .02 & 0.15 \\
\hline $\mathrm{NF}$ & \multirow{2}{*}{$\begin{array}{l}\text { Trget } \\
\text { quay }\end{array}$} & 1 & .11 & 35 & $<$ LOD & 0.23 & 4.04 & $\underline{79.5}$ & 37 & 0.06 & 9.72 & 146 & .44 & $<\mathrm{LOD}$ & $<$ LOD & 730 & 1.38 & 2.29 \\
\hline $3 \mathrm{~F}$ & & $\underline{18.0}$ & 0.12 & 0.33 & $<$ LOD & 0.35 & 3.98 & 57.9 & 2.20 & $<$ LOD & 9.47 & 124 & 0.32 & $<\mathrm{LOD}$ & 3.32 & 8,600 & 1.71 & 0.58 \\
\hline \multicolumn{2}{|l|}{ WSW $^{a}$} & 10.0 & 0.11 & 0.30 & 0.01 & 0.03 & 3.20 & 2.00 & 2.50 & 0.30 & 0.20 & 2.00 & 0.56 & 0.25 & 4.90 & 7,900 & 3.70 & 0.20 \\
\hline $\mathrm{NF}$ & \multirow[t]{2}{*}{ Štalije } & 9.98 & 0.12 & $\underline{0.16}$ & 0.02 & 0.01 & 2.52 & 53.9 & 1.93 & 0.30 & 6.13 & 55.1 & 0.52 & 0.29 & 0.03 & $\underline{6,560}$ & $\underline{0.83}$ & $\underline{78.3}$ \\
\hline $\mathrm{F}$ & & 57 & $\underline{0.11}$ & 16 & 0.02 & 0.13 & 2.73 & 19.7 & $\underline{1.89}$ & 0.26 & 6.25 & 44.9 & 0.54 & 0.39 & 1.00 & 580 & $\underline{0.86}$ & 24.4 \\
\hline 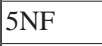 & \multirow[t]{2}{*}{ PPV } & Ts & 5 & 5 & 0.01 & 0.3 & 1.66 & .3 & 8 & 0.40 & 4 & 69.5 & 1 & 0.3 & 2.55 & 0 & 59 & 2.85 \\
\hline $5 \mathrm{~F}$ & & $\underline{8.25}$ & $\underline{0.06}$ & 04 & 0.01 & 1.28 & 1.53 & 39.4 & 3.38 & 0.52 & 27.5 & 67.6 & $\underline{0.90}$ & 0.69 & 6.41 & .860 & $\underline{0.58}$ & 2.81 \\
\hline $\mathrm{NF}$ & \multirow[t]{2}{*}{ Krapan } & 12.3 & 0.08 & 0.01 & 0.04 & 0.05 & 2.02 & 45.5 & 3.92 & 0.86 & 0.82 & 26.4 & 1.31 & 0.11 & 0.49 & 848 & 0.30 & 7.37 \\
\hline $6 \mathrm{~F}$ & & $\underline{12.5}$ & 0.07 & 0.002 & $\underline{0.04}$ & 0.14 & 1.86 & 12.7 & $\underline{4.08}$ & 0.90 & 0.80 & 5.95 & 1.41 & 0.22 & 1.65 & $\underline{893}$ & $\underline{0.32}$ & $\underline{7.10}$ \\
\hline \multirow[t]{2}{*}{ WRW $^{\mathrm{a}}$} & 14 & 0.51 & 0.30 & 0.05 & 0.02 & 0.70 & 0.05 & 108 & 2.70 & 1.13 & 77.0 & 285 & 3.40 & 1.20 & 26.0 & 385 & 0.60 & 0.50 \\
\hline & $\mathbf{F}$ & 0.05 & 0.02 & 0.01 & 0.01 & 0.10 & 0.04 & 96 & 0.50 & 1.10 & 29.0 & 76 & 0.52 & 0.40 & 5.00 & 11.7 & 0.20 & 1.00 \\
\hline NF & \multirow{2}{*}{$\begin{array}{l}\text { Drinking } \\
\text { water }\end{array}$} & 2.00 & 0.05 & 0.003 & 0.01 & 2.31 & 0.74 & 11.7 & 0.72 & 0.41 & 5.91 & 33.4 & 1.14 & 40.3 & 403 & 185 & 0.21 & 1.08 \\
\hline $7 \mathrm{~F}$ & & 1.97 & 0.06 & 0.002 & 0.01 & 2.19 & 0.68 & 5.42 & 0.72 & 0.43 & 6.40 & 30.2 & 1.29 & 41.8 & 418 & 192 & 0.22 & 1.16 \\
\hline \multicolumn{2}{|l|}{ DWG $^{\mathbf{b}}$} & & 5.00 & & 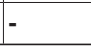 & 10.0 & - & 200 & 5.00 & 50.0 & 50.0 & 200 & 20.0 & 2,000 & 3,000 & & 10.0 & 10.0 \\
\hline
\end{tabular}

the port Bršica (e.g. ships freely unloading dirty ballastwaters, all kinds of waste deriving from cattle, and other local anthropogenic activities). Strontium and arsenic were elevated in stream samples, possibly due to seawater intrusions (brackish site no. 4), weathering of carbonate rocks containing $\mathrm{Sr}$, but some geochemical as well as technogenic (industrial legacy) processes associated with SHOS coal might also have been involved.

\subsection{Element levels in garden soil, vegetable, and aquatic sediment samples}

Table 2 shows element values in aquatic sediment, garden soil, and vegetables (lettuce and potato). Compared with reference levels, all measured elements could be considered as increased in at least one of the analysed environmental and alimentary matrices, but the highest incidence of elevated levels were determined for $\mathrm{Cu}$ and Se. However, it depends on the choice of reference values. For example, vanadium is not elevated in soil if its values are compared with the Croatian regional background for the terra rossa soil type (i.e. $148 \mathrm{mg} / \mathrm{kg}$ ), but Reimann \& de Caritat (1998) report that the maximum tolerable $\mathrm{V}$ concentration in agricultural soil is $50 \mathrm{mg} / \mathrm{kg}$ V (in Germany). Similarly, Se is increased in the Raša garden soil compared to the median value $(1.15 \mathrm{mg} / \mathrm{kg})$ representative of the background in EU countries (Halamić et al., 2012), and to the soil world median data of $0.30 \mathrm{mg} / \mathrm{kg}$ (Reimann \& de Caritat, 1998), but the maximum tolerable Se concentration in agricultural soil is $10 \mathrm{mg} / \mathrm{kg}$ (in Germany). Yang et al. (1983) reported $7.87 \mathrm{mg} / \mathrm{kg}$ total $\mathrm{Se}$ in soil from the aforemen- tioned selenosis locality in China, but recently, Tan et al. (2002) found lower Se levels there, up to $3.81 \mathrm{mg} / \mathrm{kg}$, with an average of $2.31 \mathrm{mg} / \mathrm{kg}$, the levels are very similar to the Raša garden soil Se. Since selenium is a redoxsensitive element, future studies should be focused on its speciation. Naftz \& Rice (1989) note that the oxidised form of $\mathrm{Se}$, selenate $\left(\mathrm{SeO}_{4}{ }^{2-}\right)$, is mobile in alkaline, oxidising conditions, which are fairly characteristic for the Raša study area due to carbonate bedrock and a proximity of the Adriatic seawater. Element levels in studied soil have probably resulted from the historic practice of Raša inhabitants who had introduced SHOS coal and ash into their garden plots (personal communication), thus having contaminated them to varying degrees with $\mathrm{Se}$, $\mathrm{U}, \mathrm{Cd}, \mathrm{Hg}, \mathrm{Cu}$, and other potentially toxic trace elements (see Table 2). Future studies should focus on Raša soil organisms to understand an impact of coal-derived Se on different components of the Raša soil ecosystem. Namely, Štolfa et al. (2017) report that their study on the effects of Se on wheat and earthworms showed a significant impact on measured biochemical responses. The authors discovered changes in enzyme activities in both species, which indicates a disruption of homeostasis.

Furthermore, $\mathrm{Cu}, \mathrm{Cr}, \mathrm{Se}$, and As are slightly increased in both the vegetables, where potato Se value equals a former minimum potato value (range $0.3-5.0 \mathrm{mg} / \mathrm{kg} \mathrm{Se}$ d.w.) determined at the aforementioned selenosis locality in China (Yang et al., 1983). According to Terry et al. (2000), Se levels in crops growing on soils with moderate $\mathrm{Se}$ concentrations rarely exceed $1.00 \mathrm{mg} / \mathrm{kg} \mathrm{Se}$ (d.w.). Compared to lettuce from Eastern Croatia (Kla- 
Medunić, G., Kuharić, Ž., Fiket, Ž., Bajramović, M., Singh, A.L., Krivohlavek, A., Kniewald, G., Dujmović, L.

Table 2: Concentrations (d.w. - dry weight basis) of measured elements in aquatic sediments, garden soils, and vegetable (lettuce and potato) parts (site names explained in main text and Fig. 1). Reference values: Frančišković-Bilinski et al.

$(\mathbf{2 0 1 4})^{\mathrm{a}}$, Halamić \& Miko, (eds) (2009) ${ }^{\mathrm{b}}$, Kabata-Pendias (2010) ${ }^{\mathrm{c}}$. Underlined values exceed relevant reference levels

\begin{tabular}{|c|c|c|c|c|c|c|c|c|c|c|c|c|}
\hline $\begin{array}{l}\mathrm{mg} / \mathrm{kg} \\
\text { d.w. }\end{array}$ & $\begin{array}{c}\text { Sed. } \\
\text { (no. 4) }\end{array}$ & $\begin{array}{c}\text { Sed. } \\
\text { (no. 5) }\end{array}$ & Soil 1 & Soil 2 & Lettuce root 1 & Lettuce 1 & Potato root 2 & Potato 2 & Sed. ${ }^{a}$ & Soil $^{\mathrm{b}}$ & Lettuce $^{c}$ & Potato $^{c}$ \\
\hline $\mathrm{Cu}$ & 93.8 & 71.2 & $\underline{65.5}$ & $\underline{53.2}$ & 10.1 & $\underline{12.9}$ & 18.1 & $\underline{6.52}$ & 28.9 & 31.0 & $6.00-8.00$ & 4.40 \\
\hline $\mathrm{Cd}$ & $\underline{0.33}$ & $\underline{0.42}$ & 0.48 & 0.42 & 0.29 & 0.39 & 0.42 & 0.10 & 0.26 & 0.40 & $0.03-0.40$ & $0.016-0.3$ \\
\hline $\mathrm{Zn}$ & $\underline{129}$ & $\underline{227}$ & $\underline{201}$ & 109 & 32.9 & 51.8 & 64.0 & 12.3 & 70.4 & 108 & $44.0-73.0$ & 17.0 \\
\hline $\mathrm{Pb}$ & 9.18 & $\underline{39.9}$ & 38.1 & 48.8 & 0.84 & 0.81 & 1.84 & 0.20 & 21.2 & 48.0 & $0.70-3.60$ & $0.50-3.00$ \\
\hline $\mathrm{Cr}$ & 46.3 & $\underline{76.5}$ & 62.6 & 55.4 & 2.45 & $\underline{6.07}$ & 5.28 & $\underline{0.80}$ & 44.9 & 60.0 & $0.03-0.06$ & 0.04 \\
\hline $\mathrm{Sr}$ & 161 & 172 & $\underline{136}$ & $\underline{169}$ & 21.6 & 32.6 & 35.8 & $\underline{8.03}$ & 224 & 117 & 74.0 & 2.60 \\
\hline $\mathrm{V}$ & $\underline{47.2}$ & $\underline{40.9}$ & 52.1 & 113 & 3.73 & $\underline{1.25}$ & 3.83 & 0.09 & 32.8 & 148 & $0.28-0.71$ & $0.46-0.61$ \\
\hline $\mathrm{Se}$ & $\underline{10.8}$ & $\underline{3.37}$ & $\underline{2.71}$ & 2.53 & 1.03 & $\underline{1.99}$ & 0.74 & $\underline{0.29}$ & 0.63 & $0.30^{*}$ & $0-0.02$ & $0.04-0.23$ \\
\hline $\mathrm{U}$ & $\underline{4.42}$ & $\underline{1.38}$ & 2.58 & 2.44 & 0.09 & 0.04 & 0.15 & 0.01 & 0.49 & 2.32 & - & - \\
\hline As & 0.54 & 1.12 & 1.31 & 1.18 & 0.31 & $\underline{0.25}$ & 0.49 & $\underline{0.04}$ & 6.54 & 17 & $0.02-0.05$ & $0.01-0.02$ \\
\hline $\mathrm{Hg}$ & 0.22 & 0.61 & 0.15 & $\underline{0.12}$ & 0.01 & 0.01 & 0.02 & 0.004 & 2.49 & 0.06 & 0.03 & 0.013 \\
\hline
\end{tabular}

pec et al., 2004) and Greece (Pappa et al., 2006), Se in Raša lettuce is increased approximately five-fold, and 20-fold, respectively. Lemly (1997) pointed out that Se has a strong tendency for bioaccumulation, posing toxic hazards by entering the food chain. Considering the fact that plants preferentially accumulate selenate (Barceloux, 1999), which should be mobile at the study locality, a high Raša lettuce Se value was somewhat expected. Stančić et al. (2016) reported metal levels in lettuce from a Croatian market as follows (mg/kg d.w.): As 0.10, Cd 1.16, Cr < DL, Cu 9.8, Hg 0.01, Pb 1.22, and Zn 90.3. By comparing them with values in Table 2 , it can be said that values are only partly comparable. Teklić et al. (2008) discovered that the exposure of lettuce plants to excessive copper in nutrient medium resulted with altered plant metabolism due to oxidative stress. Relationships among the two vegetables and Raša soil were assessed using the accumulation coefficient $\left(\mathrm{AC}=\mathrm{C}_{\text {root, leaf, }}\right.$ or tuber $/ \mathrm{C}_{\text {soil }}$, where the former represents an element concentration in different parts of a plant, while the latter is an element concentration in soil), and translocation factor $\left(\mathrm{TF}=\mathrm{C}_{\text {leaf or tuber }} / \mathrm{C}_{\text {root }}\right)$. Contrary to the potato, the measured elements were mostly accumulated in lettuce leaves rather than the roots, which is visible from their accumulation coefficients, and are defined as the plant/ soil concentration quotient. Their range in the lettuce leaves was 0.01-0.81 ( $\mathrm{Cd}>\mathrm{Se}>\mathrm{Zn}>\mathrm{Sr}>\mathrm{Cu}>\mathrm{As}>\mathrm{Cr}>\mathrm{Hg}>$ $\mathrm{V}=\mathrm{Pb}>\mathrm{U}$ ), while in the roots it was slightly lower, 0.02$0.60(\mathrm{Cd}>\mathrm{Se}>\mathrm{As}>\mathrm{Zn}=\mathrm{Sr}>\mathrm{Cu}>\mathrm{V}=\mathrm{Hg}>\mathrm{Cr}>\mathrm{U}>\mathrm{Pb})$. On the other hand, the accumulation coefficients of the analysed elements, all except $\mathrm{Cd}$, in the potato tubers ranged only 0.001-0.12 $(\mathrm{Cu}>\mathrm{Se}=\mathrm{Zn}>\mathrm{Sr}>\mathrm{As}=\mathrm{Hg}>\mathrm{Cr}>\mathrm{U}=\mathrm{Pb}>\mathrm{V})$, while in the roots it was slightly higher, 0.03-0.59 $(\mathrm{Zn}>\mathrm{As}>\mathrm{Cu}>\mathrm{Se}>\mathrm{Sr}>\mathrm{Hg}>\mathrm{Cr}>\mathrm{U}>\mathrm{Pb}>\mathrm{V})$; the relevant values for $\mathrm{Cd}$ were the highest in the potato, i.e. 1.00 and 0.24 . Herewith, the analysed vegetables exhibited the highest rate of Cd uptake from the Raša garden soil. According to Adriano (2001), numerous studies have shown that $\mathrm{Cd}$ is readily taken up by the roots and dis- tributed throughout the plant. In spite of the high bioavailability of $\mathrm{Cd}$ to plants, the author emphasizes that only a small fraction $(<1 \%)$ of the $\mathrm{Cd}$ pool in soils is recovered by plants due to its phytotoxicity which drastically reduces plant yield. Noteworthy, selenium mostly occupied the second or the third places in the mentioned AC orders, having exhibited one of the highest bioavailabilities (owing to chemical similarity to $\mathrm{S}$ ) to analysed vegetables, while the opposite can be said for $\mathrm{U}$ and $\mathrm{V}$. The translocation factor is an estimate of the transfer of measured elements from roots to leaves/tubers. Its range calculated for lettuce was 0.33-2.48 ( $\mathrm{Cr}>\mathrm{Se}>\mathrm{Zn}>\mathrm{Sr}>\mathrm{Cd}$ $>\mathrm{Cu}>\mathrm{Hg}>\mathrm{Pb}>\mathrm{As}>\mathrm{U}>\mathrm{V}$ ), and for the potato it was much lower, 0.02-0.39 $(\mathrm{Se}>\mathrm{Cu}>\mathrm{Cd}>\mathrm{Sr}>\mathrm{Hg}>\mathrm{Zn}>\mathrm{Cr}>\mathrm{Pb}>\mathrm{As}>$ $\mathrm{U}>\mathrm{V}$ ). Similarly to AC, Se showed one of the highest translocation levels, and the opposite was valid for $U$ and V. Herewith, lettuce proved to be a higher accumulator of selenium than the potato at the Raša study locality. However, Raša inhabitants do not rely solely on locally grown food, and therefore their diet should not pose a significant risk for their health.

Aquatic sediment collected from the site no. 4 is highly enriched in Se (see Table 2), positively correlating with the highest water Se levels (see Table 1). The site has been fed (and contaminated) by the water coming from the former coal-separation unit Štalije. Lemly (2008) note that $\mathrm{Se}$ in sediments remains active through recycling processes which bring it back into the water and food chain. The sediment sample is also enriched in $\mathrm{U}$ and $\mathrm{V}$, thus evidencing the presence of SHOS Raša coal particles in its matrix. The site seems a rather shallow wetland with probably low flushing rates, and such systems are prone to the most efficient accumulation of Se (Lemly, 1997). The author elaborated a case of a US lake which was contaminated by Se in wastewater (150$200 \mu \mathrm{g} / \mathrm{L} \mathrm{Se}$ ) released from a coal-fired facility. In spite of lake Se of only $10 \mu \mathrm{g} / \mathrm{L}$ (much lower than the Raša water no. 4, Table 1), Se concentrations were accumulated from 519 times (periphyton) to 3,975 times (vis- 
Table 3: Concentrations (w.w. - wet weight basis) of measured elements in non-migratory bird (pigeon, jay, and black coot) tissues. Reference values: $\mathrm{Cu}, \mathrm{Cd}, \mathrm{Zn}, \mathrm{Pb}, \mathrm{Sr}, \mathrm{V}, \mathrm{Se}-\mathrm{d}$.w. data were recalculated to w.w. data assuming $70 \%$ of water content in bird (white-chinned petrel, black-browed albatross, and grey-headed albatross) tissues (Kim et al., 1998); As and Hg in gull - w.w. data (Savinov et al., 2003). Underlined values exceed relevant reference levels

\begin{tabular}{|c|c|c|c|c|c|c|c|c|c|c|c|c|c|c|c|}
\hline \multirow{2}{*}{$\begin{array}{l}\mathrm{mg} / \mathrm{kg} \\
\text { w.w. }\end{array}$} & \multicolumn{4}{|c|}{ Pigeon } & \multicolumn{4}{|c|}{ Jay } & \multicolumn{3}{|c|}{ Black coot } & \multicolumn{4}{|c|}{ Reference values } \\
\hline & kidney & heart & muscle & liver & kidney & heart & muscle & liver & heart & muscle & liver & kidney & heart & muscle & liver \\
\hline $\mathrm{Cu}$ & 0.96 & $\underline{8.61}$ & 0.45 & $\underline{6.26}$ & 1.49 & 0.90 & 2.44 & 3.71 & $\underline{7.22}$ & $\underline{11.9}$ & 3.45 & $\begin{array}{c}3.69- \\
6.18\end{array}$ & $\begin{array}{l}0.07- \\
3.12\end{array}$ & $\begin{array}{l}2.37- \\
3.88\end{array}$ & $\begin{array}{l}3.61- \\
5.15\end{array}$ \\
\hline $\mathrm{Cd}$ & 0.01 & $<\mathrm{LOD}$ & $<\mathrm{LOD}$ & $<\mathrm{LOD}$ & 0.01 & 0.01 & $<\mathrm{LOD}$ & 0.09 & $<\mathrm{LOD}$ & $<\mathrm{LOD}$ & 0.07 & $\begin{array}{c}16.9- \\
54.5\end{array}$ & $\begin{array}{c}0.06- \\
1.74\end{array}$ & $\begin{array}{c}0.18- \\
1.21\end{array}$ & $\begin{array}{l}1.25- \\
10.7\end{array}$ \\
\hline $\mathrm{Zn}$ & 24.0 & 16.4 & 10.7 & $\underline{102}$ & 17.5 & 9.08 & 11.3 & 22.2 & 22.5 & 9.36 & 35.7 & $\begin{array}{c}38.2- \\
53.6\end{array}$ & $\begin{array}{l}0.07- \\
26.1\end{array}$ & $\begin{array}{l}17.6- \\
21.6\end{array}$ & $\begin{array}{c}33.3- \\
58.8\end{array}$ \\
\hline $\mathrm{Pb}$ & 0.09 & 58.3 & $\underline{0.17}$ & 0.08 & 0.03 & 0.05 & $\underline{15.3}$ & 0.11 & 0.03 & 0.02 & $\underline{0.12}$ & $\begin{array}{c}0.009- \\
0.10\end{array}$ & $\begin{array}{c}0.01- \\
0.05\end{array}$ & $\begin{array}{c}0.004- \\
0.02\end{array}$ & $\begin{array}{c}0.005- \\
0.09\end{array}$ \\
\hline $\mathrm{Cr}$ & 0.04 & 0.03 & 0.01 & 0.04 & 0.08 & 0.03 & 0.05 & 0.03 & 0.08 & 0.04 & 0.05 & - & - & - & - \\
\hline $\mathrm{Sr}$ & 0.02 & 0.03 & 0.01 & 0.02 & 0.08 & 0.04 & $\underline{0.32}$ & 0.04 & 0.05 & $\underline{0.37}$ & 0.17 & $\begin{array}{l}0.28- \\
2.25\end{array}$ & $\begin{array}{c}0.06- \\
1.54\end{array}$ & $\begin{array}{c}0.09- \\
0.14\end{array}$ & $\begin{array}{c}0.06- \\
0.69\end{array}$ \\
\hline V & 0.01 & 0.01 & $<\mathrm{LOD}$ & 0.02 & 0.05 & 0.02 & 0.01 & 0.03 & 0.01 & 0.01 & $\underline{0.15}$ & $\begin{array}{c}0.05- \\
0.12\end{array}$ & $\begin{array}{l}0.02- \\
0.06\end{array}$ & $\begin{array}{c}0.01- \\
0.04\end{array}$ & $\begin{array}{c}0.02- \\
0.08\end{array}$ \\
\hline $\mathrm{Se}$ & 0.56 & 0.26 & 0.18 & 0.50 & 0.23 & 0.31 & 0.25 & 0.56 & 0.81 & 0.75 & 1.46 & $\begin{array}{c}11.5- \\
15.7\end{array}$ & $\begin{array}{l}0.05- \\
7.00\end{array}$ & $\begin{array}{l}1.98- \\
2.13\end{array}$ & $\begin{array}{c}5.54- \\
11.9\end{array}$ \\
\hline $\mathrm{U}$ & $<\mathrm{LOD}$ & $<$ LOD & $<\mathrm{LOD}$ & $<\mathrm{LOD}$ & $<\mathrm{LOD}$ & $<\mathrm{LOD}$ & $<\mathrm{LOD}$ & $<$ LOD & $<\mathrm{LOD}$ & $<$ LOD & 0.001 & - & - & - & - \\
\hline As & 0.04 & 0.02 & 0.01 & 0.02 & 0.03 & 0.02 & 0.03 & 0.02 & 0.04 & 0.06 & 0.08 & - & - & $\begin{array}{l}1.04- \\
2.55\end{array}$ & $\begin{array}{l}2.91- \\
3.59\end{array}$ \\
\hline $\mathrm{Hg}$ & $<\mathrm{LOD}$ & $<\mathrm{LOD}$ & 0.02 & 0.02 & 0.04 & 0.04 & 0.07 & 0.08 & 0.05 & 0.04 & 0.08 & - & - & $\begin{array}{c}0.13- \\
0.50\end{array}$ & $\begin{array}{c}0.97- \\
1.38\end{array}$ \\
\hline
\end{tabular}

ceral tissue of fish) in the biota. The author pointed out that sediment Se levels of 1-4 $\mathrm{mg} / \mathrm{kg}$ (much lower than the Raša sediment no. 4, Table 2) were sufficiently elevated to contaminate benthic food organisms of fish and aquatic birds. Finally, Lemly (1997) concluded that recovery of the lake was slow, and toxic effects were evident 10 years after the selenium inputs stopped. Table 2 shows that both the sediments (no. 4 and 5) are polluted not just with SHOS Raša coal-derived Se-U-V association, but also with other potentially toxic trace elements, i.e. $\mathrm{Cu}, \mathrm{Cd}, \mathrm{Zn}, \mathrm{Pb}$, and $\mathrm{Cr}$, which were not elevated in water samples though (see Table 1).

\subsection{Element levels in tissues of three birds from the Raša Bay area}

Table 3 presents the levels of measured elements in tissues (muscle, kidney, heart, and liver) of three nonmigratory birds, i.e. pigeon, jay, and black coot. Generally, pigeon and jay can be found close to people's houses, eating various on-site food and leftovers, while black coot is more associated with wilderness and aquatic habitats. While comparing their element data with selected literature values (Kim et al., 1998; Savinov et al., 2003), it can be seen that selenium cannot be regarded as increased in any of the analysed samples. Ohlendorf \& Heinz (2011) report selenium values in birds' liver, kidney, and muscle in the following ranges $(\mathrm{mg} / \mathrm{kg})$ : adequate 1.2-3.3 d.w. (0.35-1.0 w.w.), high 6.6-20 d.w. (2-6 w.w.), and toxic 13-76 d.w. (4-23 w.w.); adequate 2.25.2 d.w. (0.5-1.2 w.w.), and high 6.4-22 d.w. (1.5-5.2 w.w.); adequate 0.49-4.9 d.w. (0.13-1.3 w.w.), and high 1.5-21 d.w. (0.4-5.5 w.w.), respectively. Although the black coot's liver Se (1.46 mg/kg w.w.) marginally approaches the lower limit of the respective high range class of 2-6 mg/kg w.w., the class itself means that Se levels are excessive but not considered toxic to poultry (Ohlendorf \& Heinz, 2011). The authors emphasize that Se's ability to interact with other nutrients and environmental contaminants, especially other elements, sometimes complicates an interpretation of toxic thresholds in tissues of birds. Data (see Table 3) shows that among the three birds, the black coot's tissues are the most contaminated in terms of $\mathrm{Cu}, \mathrm{Pb}, \mathrm{Sr}$, and $\mathrm{V}$. For example, its $\mathrm{V}$ is approximately 5-7 times the respective levels of other two birds, while that number is 3-4 in case of Se. Therefore, possible future studies should target the black coot population (Lemly, 1996) and similar birds to elucidate cause and effect relationships.

\section{Conclusions}

The study showed that the historic SHOS Raša coal industry has left an adverse effect on the environment of the Raša Bay area. Due to an enrichment of Raša coal in $\mathrm{Se}, \mathrm{V}$, and $\mathrm{U}$, the same elements were found to be fairly elevated in surface water streams, aquatic sediment, garden soil, and vegetable samples, while V only moderately in the liver of a black coot bird. An approximate order of Raša coal-derived contamination of the environment with $\mathrm{Se}, \mathrm{V}$, and $\mathrm{U}$ was as follows: surface water 
$=$ aquatic sediment $>$ lettuce $>$ garden soil $>$ potato $>$ black coot liver. Since excessive selenium exposure can result in toxic effects and health problems, the polluted Raša Bay sites should be inspected more thoroughly, technically improved, and monitored to protect the environment as well as the health of local inhabitants. Future analytical approaches will be oriented towards selenium speciation as it dictates the environmental fate of this element and the variability of its toxicity. Moreover, environmental matrices, primarily soil, will be tested by a bioremediation technological clean up method.

\section{Acknowledgment}

We are pleased to thank a hunter Mr Emilio Mendiković (Labin) for providing us with birds from the Raša Bay area. We also acknowledge Mrs Jasenka Šabarić for her help and kindness. Financial support from the Croatian Science Foundation through the project 7555 TRACESS is acknowledged. The first author (G.M.) acknowledges the TECO grant "EU-India project TECO ICI+/2014/342-817-Technological eco-innovation for the quality control and the decontamination of polluted waters and soils".

\section{References}

Adriano, D.C. (2001): Trace elements in terrestrial environments. Biogeochemistry, Bioavailability, and Risks of Metals. Springer Verlag, New York, 867 pp.

Banerjee, T., Kumar, M., Mall, R.K., Singh, R.S. (2016): Airing 'clean air' in Clean India Mission. Environmental Science and Pollution Research, 24(7), doi: 10.1007/ s11356-016-8264-y

Barceloux, D.G. (1999): Selenium. Clinical Toxicology, 37(2), 145-172.

Baruah, B.P., \& Khare, P. (2010): Mobility of trace and potentially harmful elements in the environment from high sulfur Indian coal mines. Applied Geochemistry, 25, 1621-1631.

Clarke, L.B. and Sloss, L.L. (1992): Trace Elements - Emissions from Coal Combustion and Gasification, IEACR/49, IEA Coal Research, London, 111pp.

Dai, S., Seredin, V.V., Ward, C.R., Hower, J.C., Xing, Y., Zhang, W., et al. (2015): Enrichment of U-Se-Mo-Re-V in coals preserved within marine carbonate successions: geochemical and mineralogical data from the Late Permian Guiding Coalfield, Guizhou, China. Mineralium Deposita, 50, 159-186.

Dai, S., Finkelman, R. (2017): Coal as a promising source of critical elements: Progress and future prospects. International Journal of Coal Geology, https://doi.org/10.1016/j. coal.2017.06.005.

Das, T., Chauhan, H., Deka, S., Chaudhary, S., Boruah, R., Saikia, B.K. (2017): Promising carbon nanosheet-based supercapacitor electrode materials from low-grade coals. Microporous and Mesoporous Materials, 253, 80-90.

Diaz, J.P., Navarro, M., Lopez, H., Lopez, M.C. (1996): Selenium (IV) and (VI) levels in potable, irrigation and waste waters from an industrial zone in southeastern Spain. The Science of the Total Environment, 186, 231-236.

Dreher, G.B., Finkelman, R.B. (1992): Selenium mobilization in a surface coal mine, Powder River Basin, Wyoming, U.S.A. Environmental Geology and Water Sciences, 19, 155-167.

Durn, G., Ottner, F., Slovenec, D. (1999): Mineralogical and geochemical indicators of the polygenetic nature of terra rossa in Istria, Croatia. Geoderma, 91, 125-150.

Fiket, Ž., Roje, V., Mikac, N., Kniewald, G. (2007): Determination of arsenic and other trace elements in bottled waters by high resolution inductively coupled plasmamass spectrometry. Croatica Chemica Acta, 80, 91-100.

Fiket, Ž., Medunić, G., Kniewald, G. (2016): Rare earth elements distribution in soil nearby thermal power plant. Environmental Earth Sciences, 75: 598, doi:10.1007/s12665016-5410-2.

Fiket, Ž., Medunić, G., Furdek Turk, M., Ivanić, M., Kniewald, G. (2017): Influence of soil characteristics on rare earth fingerprints in mosses and mushrooms : example of a pristine temperate rainforest (Slavonia, Croatia). Chemosphere 179, 92-100.

Frančišković-Bilinski, S., Scholger, R., Bilinski, H., Tibljaš, D. (2014): Magnetic, geochemical and mineralogical properties of sediments from karstic and flysch rivers of Croatia and Slovenia. Environmental Earth Sciences, 72, 3939-3953.

Halamić, J., Miko, S. (eds) (2009): Geochemical Atlas of the Republic of Croatia. Croatian Geological Survey, 87 pp, Zagreb.

Halamić, J., Peh, Z., Miko, S., Galović, L., Šorša, A. (2012): Geochemical atlas of Croatia: environmental implications and geodynamical thread. Journal of Geochemical Exploration, 115, 36-46.

Harkness, J.S., Sulkin, B., Vengosh, A. (2016): Evidence for coal ash ponds leaking in the Southeastern United States. Environmental Science and Technology, 50, 6583-6592.

Helios Rybicka, E. (1996): Impact of mining and metallurgical industries on the environment in Poland. Applied Geochemistry, 11, 3-9.

Juračić, M., Sondi, I., Prohić, E., Pravdić, V. (1994): Sedimentation in a microtidal, rock-bounded estuary - a model for land/sea transfer systems in karstic regions: the Raša River estuary. Proceedings of Symposium Littoral 94. Eurocast Meeting, Lisboa, 549-559.

Kabata-Pendias, A. (2010): Trace elements in solis and plants. 4th edition. CRC Press/Taylor \& Francis Group, Boca Raton, FL, USA, ISBN: 978-1-4200-9368-1, 548 pp.

Kim, E.Y., Goto, R., Tanabe, S., Tanaka, H., Tatsukawa, R. (1998): Distribution of 14 elements in tissues and organs of oceanic seabirds. Archives of Environmental Contamination and Toxicology, 35, 638-645.

Klapec, T., Mandić, M.L., Grgić, J., Primorac, Lj., Perl, A., Krstanović, V. (2004): Selenium in selected foods grown or purchased in eastern Croatia. Food Chemistry, 85, 445-452.

Kumar, M., Singh, R.S., Banerjee, T. (2015): Associating airborne particulates and human health: Exploring possibilities. Environment International, 84, 201-202. 
Lemly, A.D. (1993): Guidelines for evaluating selenium data from aquatic monitoring and assessment studies. Environmental Monitoring and Assessment, 28, 83-100.

Lemly, A.D. (1996): Assessing the toxic threat of selenium to fish and aquatic birds. Environmental Monitoring and Assessment, 43, 19-35.

Lemly, A.D. (1997): Environmental implications of excessive selenium: A review. Biomedical Environmental Sciences, $10,415-435$.

Lemly, A.D. (2004): Aquatic selenium pollution is a global environmental safety issue. Ecotoxicology and Environmental Safety, 59, 44-56.

Lemly, A.D. (2008): Aquatic hazard of selenium pollution from coal mining. In: Coal Mining: Research, Technology and Safety. Fosdyke, G.B. (ed), Nova Science Publishers, Inc., 167-183.

Medunić, G., Rađenović, A., Bajramović, M., Švec, M., Tomac, M. (2016a): Once grand, now forgotten: what do we know about the superhigh-organic-sulphur Raša coal? Rudarsko-geološko-naftni zbornik, 34, 27-45.

Medunić, G., Ahel, M., Božičević Mihalić, I., Gaurina Srček, V., Kopjar, N., Fiket, Ž., Bituh, T., Mikac, I. (2016b): Toxic airborne S, PAH, and trace element legacy of the superhigh-organic-sulphur Raša coal combustion: Cytotoxicity and genotoxicity assessment of soil and ash. Science of the Total Environment, 566, 306-319.

Medunić, G., Kuharić, Ž., Krivohlavek, A., Fiket, Ž., Rađenović, A., Gödel, K., Kampić, Š., Kniewald, G. (2017): Geochemistry of Croatian superhigh-organic-sulphur Raša coal, imported low-S coal, and bottom ash: their Se and trace metal fingerprints in seawater, clover, foliage, and mushroom specimens. International Journal of Oil, Gas and Coal Technology, doi: 10.1504/IJOGCT.2018.10006334.

Miko, S., Durn, G., Prohić, E. (1999): Evaluation of terra rossa geochemical baselines from Croatian karst regions. Journal of Geochemical Exploration, 66, 173-182.

Mohorović, L. (2003): The level of maternal methemoglobin during pregnancy in an air-polluted environment. Environmental Health Perspectives, 111, 1902-1905.

Naftz, D.L., Rice, J.A. (1989): Geochemical processes controlling selenium in ground water after mining, Powder River Basin, Wyoming, U.S.A. Applied Geochemistry, 4, 565-575.

Official Gazette (2008): Regulations on healthy drinking water control (in Croatian), 47/2008.

Ohlendorf, H.M., Heinz, G.H. (2011): Selenium in birds. In: Environmental Contaminants in Biota: Interpreting Tissue Concentrations, 2nd edition, W. Nelson Beyer \& James P. Meador Eds), Boca Raton: CRC, 669-701.

Oliveira, M.L.S., Marostega, F., Taffarel, S.R., Saikia, B.K., Waanders, F.B., DaBoit, K., Baruah, B.P., Silva, L.F. (2014): Nano-mineralogical investigation of coal and fly ashes from coal-based captive power plant (India): an introduction of occupational health hazards. Science of the Total Environment, 468-469, 1128-1137.

Pappa, E.C., Pappas, A.C., Surai, P.F. (2006): Selenium content in selected foods from the Greek market and estimation of the daily intake. Science of the Total Environment, 372, 100-108.
Rayman, M.P. (2012): Selenium and human health. Lancet, 379, 1256-1268

Reimann, C., de Caritat, P. (1998): Chemical elements in the environment. Factsheets for the geochemist and environmental scientist. Springer-Verlag Berlin Heidelberg, 398 pp.

Saikia, J., Saikia, P., Boruah, R., Saikia, B.K. (2015): Ambient air quality and emission characteristics in and around a non-recovery type coke oven using high sulphur coal. Science of the Total Environment, 530-531, 304-313.

Saikia, B.K., Dalmora, A.C., Choudhury, R., Das, T., Taffarel, S.R., Silva, L.F.O. (2016): Effective removal of sulfur components from Brazilian power-coals by ultrasonication $(40 \mathrm{kHz})$ in presence of $\mathrm{H} 2 \mathrm{O} 2$. Ultrasonics Sonochemistry, 32, 147-157.

Sasmaz, A., Obek, E. (2009): The accumulation of arsenic, uranium, and boron in Lemna gibba L. exposed to secondary effluents. Ecological Engineering, 35, 1564-1567.

Savinov, V.M., Gabrielsen, G.W., Savinova, T.N. (2003): Cadmium, zinc, copper, arsenic, selenium and mercury in seabirds from the Barents Sea: levels, inter-specific and geographical differences. The Science of the Total Environment, 306, 133-158. Sharma, N., Bhatnagar, P., Chatterjee, S., Goswami, P. (2017): Waste water microbes and environmental "clean up": roadmap to environmental sustainability. International Journal of Advanced Research in Science, Engineering and Technology, 4, 3341-3350.

Silva, L.F.O., DaBoit, K., Sampaio, C.H., Jasper, A., Andrade, M.L., Kostova, I.J., et al. (2012): The occurrence of hazardous volatile elements and nanoparticles in Bulgarian coal fly ashes and the effect on human health exposure. Science of the Total Environment, 416, 513-526.

Singh, P.K., Singh, A.L., Kumar, A., Singh, M.P. (2012): Mixed bacterial consortium as an emerging tool to remove hazardous tracemetals from coal. Fuel, 102, 227-230.

Singh, P.K., Singh, A.L., Kumar, A., Singh, M.P. (2013): Control of different pyrite forms on desulfurization of coal with bacteria. Fuel, 106, 876-879.

Sofilić, T., Brnardić, I., Šimunić-Mežnarić, V., Šorša, A. (2013): Soil pollution caused by landfilling of nonhazardous waste from steel production processes. Chemistry in industry, 62, 381-388.

Stančić, Z., Vujević, D., Gomaz, A., Bogdan, S., Vincek, D. (2016): Detection of heavy metals in common vegetables at Varaždin City Market, Croatia. Archive of Industrial Hygiene and Occupational Medicine, 67, 340-350.

Štolfa, I., Velki, M., Vuković, R., Ečimović, S., Katanić, Z., Lončarić, Z. (2017): Effect of different forms of selenium on the plant-soil-earthworm system. Journal of Plant Nutrition and Soil Science, 000, 1-10.

Tan, J., Zhu, W., Wang, W., Li, R., Hou, S., Wang, D., Yang, L. (2002): Selenium in soil and endemic diseases in China. The Science of the Total Environment, 284, 227-235.

Teklić, T., Engler, M., Cesar, V., Lepeduš, H., Parađiković, N., Lončarić, Z., Štolfa, I., Marotti, T., Mikac, N., Žarković, N. (2008): Influence of excess copper on lettuce (Lactuca sativa L.) grown in soil and nutrient solution. Journal of Food, Agriculture \& Environment, 6 (3\&4), 439-444.

Ternjej, I., Gaurina Srček, V., Mihaljević, Z., Kopjar, N. (2013): Cytotoxic and genotoxic effects of water and sediment samples from gypsum mining area in channel catfish 
ovary $(\mathrm{CCO})$ cells. Ecotoxicology and Environmental Safety, 98, 119-127.

Terry, N., Zayed, A.M., de Souza, M.P., Tarun, A.S. (2000): Selenium in higher plants. Annual Review of Plant Physiology, 51, 401-432.

Wang, X., Elshahawi, S., Shaaban, K., Fang, L., Ponomareva, L., Zhang, Y., Copley, G., Hower, J., Zhan, C, Kharel, M., Thorson, J. (2014): Ruthmycin, a novel tetracyclic polyketide from Streptomyces sp. RM-4-15. Organic Letters, 16, 456-459.
Yang, G.Q., Wang, S.Z., Zhou, R.H., Sun, S.Z. (1983): Endemic selenium intoxication of humans in China. American Journal of Clinical Nutrition, 37, 872-881.

Yudovich, Ya.E., Ketris, M.P. (2006): Selenium in coal: a review. International Journal of Coal Geology, 67, 112-126.

Zacchini, M., Pietrini, F., Mugnozza, G.S., Iori, V., Pietrosanti, L., Massacci, A. (2009): Metal tolerance, accumulation and translocation in poplar and willow clones treated with cadmium in hydroponics. Water, Air, and Soil Pollution, 197, 23-34

\section{SAŽETAK \\ Razine selena i teških metala u povrću i tkivima triju ptica stanarica izloženih tlu, vodi i riječnim sedimentima onečišćenima selenoznim rašlkim ugljenom}

Rudarenjem i spaljivanjem ugljena u okoliš se ispuštaju onečišćivala koja se tamo zadrže desetljećima. Rad donosi podatke o koncentraciji Se i teških metala (As, Cd, Cu, Cr, Hg, Pb, Sr, U, V i Zn) u salati, krumpiru i tkivima (jetra, bubreg, srce i mišići) ptica stanarica (golub, šojka, i crna liska) iz područja Raškoga zaljeva (sjeverni Jadran, Hrvatska). Njihova izloženost povišenim razinama Se i teških metala u povrtnome tlu, površinskoj vodi i riječnome sedimentu onečišćenima visokosumpornim raškim ugljenom, obogaćenom sa S, Se, V i U, vrlo je vjerojatna. Rezultati upućuju na zagađenost vode selenom (do $78 \mu \mathrm{g} / \mathrm{L}$ ukupni Se u nefiltriranome uzorku), što je znatno iznad hrvatskoga regulacijskog praga od $10 \mu \mathrm{g} / \mathrm{L}$ ukupnoga Se. Dotična voda potječe s mjesta bivše jedinice za sortiranje i pranje ugljena, a pridneni sediment sadržava do $10,8 \mathrm{mg} / \mathrm{kg}$ ukupnoga Se, što je također iznad sigurne razine od o,6o mg/kg ukupnoga Se. Štoviše, u većini uzoraka vode, kao i u analiziranim uzorcima povrća, tla i riječnoga sedimenta, povišene su vrijednosti Mo, U, V i Sr, uobičajeno povišenih u takvim ugljenima. Iako su $\mathrm{Cu}, \mathrm{Zn}, \mathrm{Pb}$ i V blago povišeni u uzorcima jetre ptica, ponajprije u crnoj liski u odnosu na ostale dvije ptice, pronađeno je da su vrijednosti Se odgovarajuće za njihov normalan rast. Činjenica da Se može biti opasan za okoliš i otrovan za život, čak i u malim količinama, dodatno potiče na daljnja znanstvena istraživanja ovoga problema.

\section{Ključne riječi:}

ugljen, selen, voda, salata, ptice

\section{Authors contribution}

Gordana Medunić (Associate Professor) initialized the idea and led the research, Mladen Bajramović (BSc.) helped with field work, Lucija Dujmović (BSc.) prepared samples for analyses, Željka Kuharić (PhD.), Adela Krivohlavek, Željka Fiket (PhD.), and Goran Kniewald conducted measurements, and Asha Lata Singh (Assistant Professor) made calculations related to soil-plant interactions and helped with botanical interpretations. All the authors equally participated in typing and editing the manuscript. 